\title{
SP1 wt Allele
}

National Cancer Institute

\section{Source}

National Cancer Institute. SP1 wt Allele. NCI Thesaurus. Code C53127.

Human SP1 wild-type allele is located in the vicinity of $12 q 13.1$ and is approximately $36 \mathrm{~kb}$ in length. This allele, which encodes transcription factor Sp1 protein, plays a role in the regulation of transcription by RNA polymerase II. 